\title{
Changes in plasma EBV-DNA and immune status in patients with nasopharyngeal carcinoma after treatment with intensity- modulated radiotherapy
}

\author{
Qi Chen ${ }^{1}$, Wei Hu${ }^{2}$, Huacai Xiong ${ }^{2}$, Shenpeng Ying ${ }^{2}$, Yanyun Ruan ${ }^{1}$, Bo Wu² and Hongsheng $\mathrm{Lu}^{2,3^{*}}$
}

\begin{abstract}
Background: Previous studies reported the early diagnostic values of plasma Epstein-Barr virus (EBV)-DNA. The present study aimed to assess the relationship between the concentration of plasma EBV-DNA and the number of CD8 ${ }^{+}$PD $-1^{+}$(programmed cell death-1,PD-1) and regulatory $T$ (Treg) cells in patients with nasopharyngeal carcinoma (NPC) who were treated with intensity-modulated radiotherapy (IMRT).

Methods: This study included 37 patients treated with IMRT. Peripheral blood samples were collected two times for each patient, before radiation therapy and 1 week after the treatment. Further, the numbers of $\mathrm{CD}_{4}^{+}, \mathrm{Treg}_{\mathrm{C}} \mathrm{CD} 8^{+}$, and $\mathrm{CD} 8^{+} \mathrm{PD} 1^{+}$cells were determined by flow cytometry.

Results: The changes after IMRT were determined by comparing the numbers of neutrophils, lymphocytes, CD4 ${ }^{+}$, Treg, $\mathrm{CD}^{+}, \mathrm{CD}^{+}{ }^{+} \mathrm{PD} 1^{+}$cells, and the concentration of plasma EBV-DNA between pretreatment and post-treatment groups. IMRT could reduce the expression level of PD-1 and the number of Treg cells. The concentration of plasma EBV-DNA and the expression level of $\mathrm{CD} 8{ }^{+} \mathrm{PD}-1^{+}$were closely associated with the occurrence and development of NPC. Thus, EBV-DNA can be used as an important marker for early diagnosis, and IMRT can strongly reduce the copies of EBV-DNA.
\end{abstract}

Conclusions: This study showed that IMRT could reverse T-cell exhaustion and reduce the copies of EBV-DNA. In clinical practice, plasma EBV-DNA is a sensitive biomarker for diagnosis, prognosis, and evaluation of clinical efficacy.

Keywords: Plasma EBV-DNA, Intensity-modulated radiotherapy, Nasopharyngeal carcinoma, PD-1, Treg cells

\section{Introduction}

Nasopharyngeal carcinoma (NPC) is one of the head and neck epithelial cancers and is a serious threat to human health. According to the latest statistics, about 80\% of patients with NPC were observed in Asia, especially in Southeast Asia and south China. Based on the previous reports, the estimated incidence rate of NPC in China was 60.6 per 100,000 , and the mortality rate was 34.1 per 100,000 [1].

\footnotetext{
* Correspondence: luhs@tzzxyy.com

${ }^{2}$ Department of Radiotherapy, Taizhou Central Hospital (Taizhou University Hospital), Taizhou, Zhejiang 318000, People's Republic of China

${ }^{3}$ Department of Pathology, Taizhou Central Hospital (Taizhou University

Hospital), Taizhou, Zhejiang, People's Republic of China

Full list of author information is available at the end of the article
}

With the development of radiotherapy techniques in recent years, intensity-modulated radiotherapy (IMRT) has been widely applied for treating patients with NPC. Also, the prognosis of early-stage NPC has been significantly improved. However, with the development of tumor treatment, a number of studies have discovered the immunogenicity of radiotherapy [2-4]. Epstein-Barr virus (EBV) causes several lymphomas and hence has been considered to cause NPC. Plasma EBV-DNA is regarded as a significant biomarker for NPC. Circulating cancer-derived EBV-DNA in plasma has been shown to be associated with the early screening of patients with NPC [5].

PD-1, a new indispensable member of CD28/B7 co-stimulating signals, is a surface inhibitory receptor having critical functions in regulating T-cell activation

(c) The Author(s). 2019 Open Access This article is distributed under the terms of the Creative Commons Attribution 4.0 International License (http://creativecommons.org/licenses/by/4.0/), which permits unrestricted use, distribution, and 
and tolerance [6]. It is also an important marker of T-cell exhaustion.

The present study aimed to determine the relationship between the concentration of plasma EBV-DNA and the numbers of $\mathrm{CD} 8{ }^{+} \mathrm{PD}-1^{+}$and regulatory $\mathrm{T}$ (Treg) cells in patients with NPC who were treated with IMRT.

\section{Materials and methods}

\section{Study population}

This was an observational study in which data were collected between July 2015 and June 2016. The criteria used in the study were according to the guidelines for diagnosis, treatment, and follow-up of NPC. A total of 40 patients with NPC were selected from Taizhou Central Hospital (Zhejiang, China). Of these, 37 patients were treated with IMRT, and the others lost the follow-up because they moved to another hospital for treatment. All patients underwent primary screening before the treatment. The basic information of these patients was collected, including age, gender, clinical stage, pathological classification, treatment regimen, and follow-up records. Patients were restaged according to the seventh edition of the American Joint Committee on Cancer tumor, node, metastasis (TNM) staging system released in 2010. Besides, 40 healthy individuals were included as controls. The demographic and clinical characteristics of the patients are summarized in Table 1. No significant difference was found in sexuality and age between patients with NPC and controls $(P>0.05)$. The clinical stages were divided into early stage and late stage (early stage $=$ I + II; late stage $=$ III + IV).

\section{Ethics statement}

This study was approved by the Ethics Committee of Taizhou Central Hospital. All patients signed the informed consent form before the samples were collected.

\section{Samples}

The peripheral blood samples $(3 \mathrm{~mL})$ were collected from patients with NPC before treatment (Pre) and after treatment (Post), and from healthy donors (HD). Anticoagulant samples were used for flow cytometry analysis. Plasma samples were centrifuged for $5 \mathrm{~min}$ at $800 \mathrm{rpm}$ and tested by plasma EBV-DNA assay.

\section{Monoclonal antibodies}

Fluorochrome-conjugated monoclonal antibodies (mAbs) were CD4-FITC (Fluoresceine isothiocyanate) clone SK3, CD25-APC (Allophycocyanin) clone 2A3, CD127-PERCP (Peridinin chlorophyll protein)-CY5.5 clone HIL-7R-M21, mouse-IgG1-FITC clone X40, mouse-IgG-PE (Phycoerythrin) clone MOPC-21, mouse-IgG1-APC clone SJ25C1, mouse-IgG1- PERCP-CY5.5 clone X40, CD4PERCP-CY5.5 clone SK3, CD8-FITC clone 2D1, and
Table 1 Baseline characteristics of the 37 patients and controls

\begin{tabular}{|c|c|c|c|}
\hline Clinical parameters & $\begin{array}{l}\text { NPC patients } \\
(N=37)\end{array}$ & $\begin{array}{l}\text { Healthy Donors } \\
(N=40)\end{array}$ & \\
\hline \multicolumn{4}{|l|}{ Age (years) } \\
\hline \multirow[t]{3}{*}{ Median (range) } & $53(37-90)$ & $50(20-73)$ & $p=0.072$ \\
\hline & $>=5319$ & $>=5022$ & \\
\hline & $<5318$ & $<5018$ & \\
\hline \multicolumn{4}{|l|}{ Gender } \\
\hline Male & 25 & 23 & $p=0.362$ \\
\hline Female & 12 & 17 & \\
\hline \multicolumn{4}{|l|}{ Clinical stage } \\
\hline I + || (early stage) & 16 & & \\
\hline III + IV (late stage) & 21 & & \\
\hline \multicolumn{4}{|l|}{ Tumor stage $\mathrm{e}^{\mathrm{a}}$} \\
\hline $\mathrm{T} 1+\mathrm{T} 2$ & 23 & & \\
\hline $\mathrm{T} 3+\mathrm{T} 4$ & 14 & & \\
\hline \multicolumn{4}{|l|}{ Lymph node stage ${ }^{a}$} \\
\hline NO & 5 & & \\
\hline $\mathrm{N} 1+\mathrm{N} 2+\mathrm{N} 3$ & 32 & & \\
\hline \multicolumn{4}{|l|}{ Metastasis stage ${ }^{a}$} \\
\hline Mo & 34 & & \\
\hline M1 & 3 & & \\
\hline \multicolumn{4}{|l|}{ Tumor differentiation } \\
\hline Keratinizing & 3 & & \\
\hline Non-Keratinizing & 34 & & \\
\hline
\end{tabular}

NPC nasopharyngeal carcinoma

${ }^{a}$ According to the AJCC tumor-node-metastases (TNM) staging system, 2010

CD279(PD-1)-PE clone EH12.1 (BD Biosciences, CA, USA).

\section{Flow cytometry analysis}

Flow cytometry analysis was performed to determine the numbers of neutrophils, lymphocytes, $\mathrm{CD}^{+}$, Treg , $\mathrm{CD} 8^{+}$, and $\mathrm{CD}^{+} \mathrm{PD}^{+}$(Fig. 1). Peripheral blood mononuclear cells were washed with phosphate-buffered saline (PBS) with 5\% heparin-activated fetal calf serum and then stained for the surface markers CD4 (FITC), CD25 (APC), and CD127 (PERCP-CY5.5)) according to the manufacturer's instructions. Another tube was added with CD8 ${ }^{+}$-FITC/PD- $1^{+}-\mathrm{PE} / \mathrm{CD} 4^{+}$- PERCP-CY5.5. The cells were washed twice with $\mathrm{PBS}$ and analyzed immediately using BD-FACS AriaII cytometer (BD Biosciences, CA, USA) and FlowJo software (BD Biosciences). Quadrants and box gates were set about isotype controls, and the percentages of the Treg and $\mathrm{CD} 8^{+} \mathrm{PD}-1^{+}$subsets were accordingly calculated.

\section{Use of hemocytometer}

Routine blood specimens were anticoagulated with K2-EDTA (Ethylene Diamine Tetraacetic Acid). Sysmex 


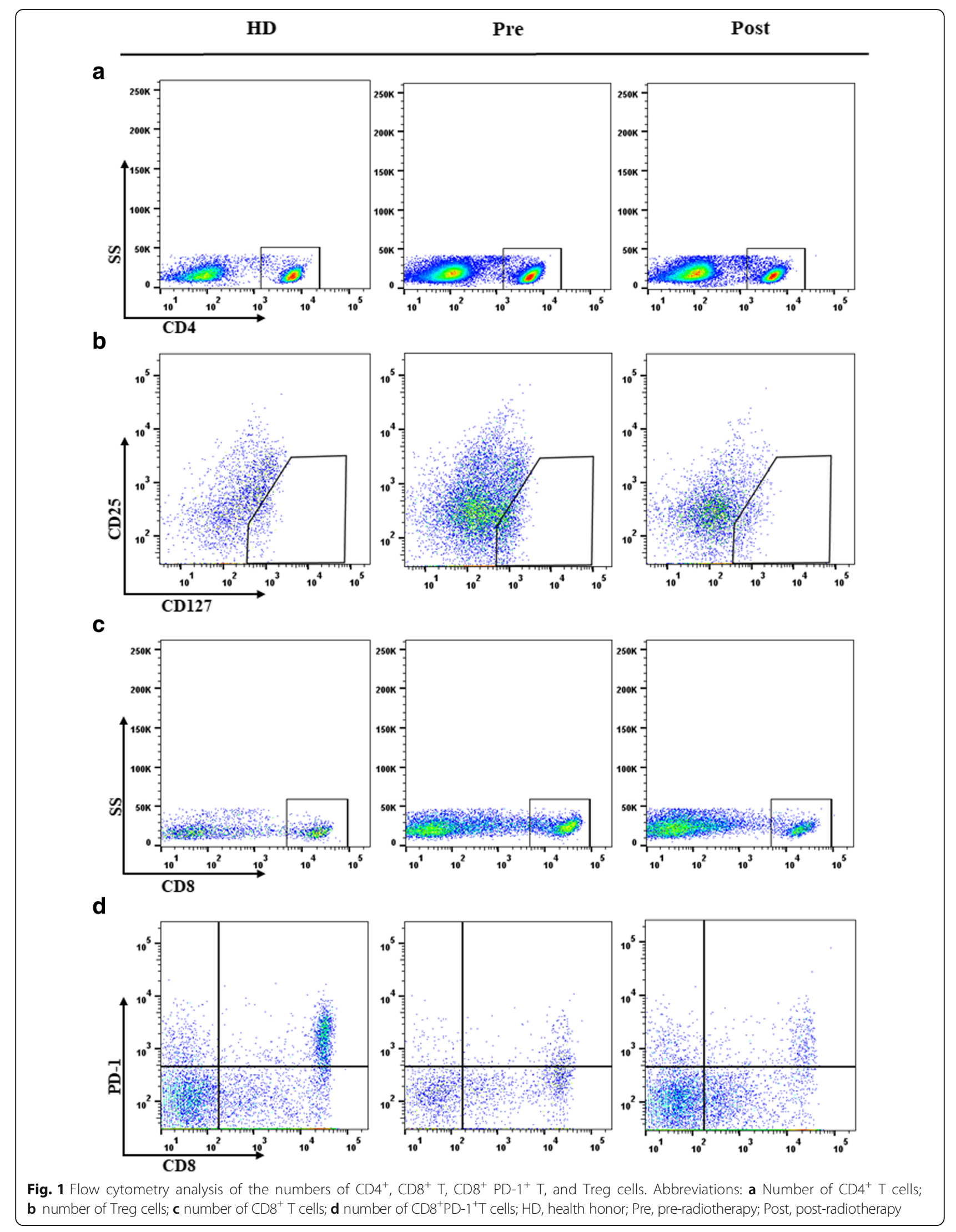


Table 2 Pre- and post-radiotherapy findings of studied patients compared with healthy levels

\begin{tabular}{|c|c|c|c|c|c|c|c|}
\hline Parameters & $H D$ & Pre & Post & $P 1$ & $P 2$ & OR & $95 \% \mathrm{Cl}$ \\
\hline $\begin{array}{l}\mathrm{N} \\
\left(10^{6} / \mathrm{ml}\right)\end{array}$ & $\begin{array}{l}3.30 \\
(2.00-5.90)\end{array}$ & $\begin{array}{l}3.90 \\
(1.70-13.20)\end{array}$ & $\begin{array}{l}3.31 \\
(0.95-23.49)\end{array}$ & 0.06 & 0.03 & 0.46 & $(0.18,1.15)$ \\
\hline $\begin{array}{l}\mathrm{L} \\
\left(10^{6} / \mathrm{ml}\right)\end{array}$ & $\begin{array}{l}2.05 \\
(1.00-3.50)\end{array}$ & $\begin{array}{l}1.30 \\
(0.20-6.00)\end{array}$ & $\begin{array}{l}0.43 \\
(0.12-2.32)\end{array}$ & 0.00 & 0.00 & 29.71 & $(3.68,239.94)$ \\
\hline $\begin{array}{l}\text { NLR } \\
\left(10^{6} / \mathrm{ml}\right)\end{array}$ & $\begin{array}{l}1.60 \\
(0.90-3.30)\end{array}$ & $\begin{array}{l}2.47 \\
(1.29-29.50)\end{array}$ & $\begin{array}{l}8.24 \\
(1.34-68.21)\end{array}$ & 0.00 & 0.00 & 0.19 & $(0.06,0.55)$ \\
\hline $\begin{array}{l}\text { EBV DNA } \\
\text { (copies/ml) }\end{array}$ & $\begin{array}{l}56.11 \\
(0.00-3213.50)\end{array}$ & $\begin{array}{l}1132.56 \\
(0.00-19065.22)\end{array}$ & $\begin{array}{l}35.67 \\
(0.00-5678.50)\end{array}$ & 0.00 & 0.00 & 0.02 & $(0.00,0.20)$ \\
\hline $\begin{array}{l}\mathrm{CD}^{+} \\
\left(10^{6} / \mathrm{ml}\right)\end{array}$ & $\begin{array}{l}0.70 \\
(0.18-1.20)\end{array}$ & $\begin{array}{l}0.37 \\
(0.05-1.09)\end{array}$ & $\begin{array}{l}0.07 \\
(0.00-073)\end{array}$ & 0.00 & 0.00 & 9.50 & $(2.81,32.10)$ \\
\hline $\begin{array}{l}\text { Treg } \\
\left(10^{6} / \mathrm{ml}\right)\end{array}$ & $\begin{array}{l}0.08 \\
(0.04-0.23)\end{array}$ & $\begin{array}{l}0.09 \\
(0.01-0.26)\end{array}$ & $\begin{array}{l}0.02 \\
(0.00-0.16)\end{array}$ & 0.68 & 0.00 & 0.86 & $(0.35,2.10)$ \\
\hline $\begin{array}{l}\mathrm{CD}^{+} \\
\left(10^{6} / \mathrm{ml}\right)\end{array}$ & $\begin{array}{l}8.49 \\
(3.02-14.85)\end{array}$ & $\begin{array}{l}3.42 \\
(0.00-7.16)\end{array}$ & $\begin{array}{l}0.22 \\
(0.00-0.75)\end{array}$ & 0.00 & 0.00 & 20.06 & $(4.21,95.56)$ \\
\hline $\begin{array}{l}\mathrm{CD} 8^{+} \mathrm{PD}^{+} \\
\left(10^{6} / \mathrm{ml}\right)\end{array}$ & $\begin{array}{l}0.19 \\
(0.05-0.45)\end{array}$ & $\begin{array}{l}0.13 \\
(0.03-0.58)\end{array}$ & $\begin{array}{l}0.05 \\
(0.01-0.19)\end{array}$ & 0.02 & 0.00 & 3.17 & $(1.21,8.30)$ \\
\hline
\end{tabular}

$N$ absolute neutrophil count, $L$ absolute lymphocyte count, $N L R$ neutrophil lymphocyte ratio, Treg $C D 4^{+} C D 25^{+} C D 127^{\text {low }}, P 1$ Healthy Donor\& Pre-radiotherapy, $P 2$ Pre-radiotherapy \&Post-radiotherapy, OR the odds ratio, $95 \% \mathrm{Cl} 95 \%$ confidence intervals

XE-2100 (Sysmex Corp., Kobe, Japan) and reagents were used to obtain the total numbers leukocytes and lymphocytes.

\section{DNA extraction and plasma EBV-DNA assay}

Polymerase chain reaction (PCR) was used to detect the concentration of plasma EBV-DNA. The plasma samples were stored at $-80^{\circ} \mathrm{C}$ for EBV-DNA assay. DNA was extracted from plasma. The concentration of EBV-DNA was measured by quantitative reverse transcription PCR (RT-qPCR).

\section{Clinical treatment}

Peripheral blood samples were collected two times for each patient before radiation therapy and 1 week after the treatment.

\section{Statistical analysis}

In the present study, SPSS 17.0 software (IBM, NY, USA) was used to analyze the data, and GraphPad Prism 6 (GraphPad Software, Inc., CA, USA) was used to generate graphs. Shapiro-Wilk test was used to test the normality of our data. As the data became skewed, the mean could not provide the best central location for the data because the skewed data dragged it away from the typical value. However, the median best retained its position and was not as strongly influenced by the skewed values. A paired $t$ test was used to compare the indexes between the pretreatment and post-treatment groups when the data were normally distributed; otherwise, the Wilcoxon signed-rank test was applied. The Mann-Whitney $U$ test was used to compare the samples between pretreatment and HD. The receiver operating characteristic (ROC) curve was used to determine the sensitivity and specificity. The chi-square test was applied to compare categorical data between the groups. One-way analysis of variance was used to compare the indexes of patients with NPC at different clinical stages. Least significant difference test was performed between every two stages. The results were considered statistically significant when the $P$ values were less than 0.05 .

\section{Results}

Description of demographic characteristics

This study included 37 patients diagnosed with NPC having no chronic diseases, such as autoimmune diseases and other inflammatory diseases. Of these, 25 were men and 12 were women. The clinical characteristics of the patients before treatment are listed in Table 1. In addition, the distributions of patients with NPC according to the TNM classification system are also presented in Table 1. Based on the last follow-up, five patients had died.

Table 3 ROC analysis for EBV DNA, Treg and CD $8^{+}$PD- $1^{+}$

\begin{tabular}{|c|c|c|c|c|}
\hline Parameters & AUC & $p$ & Sensitivity & Specificity \\
\hline L & 0.796 & 0.000 & 0.027 & 1 \\
\hline NLR & 0.775 & 0.000 & 0.892 & 0.525 \\
\hline EBV DNA & 0.912 & 0,000 & 0.838 & 0.925 \\
\hline $\mathrm{CD}^{+}$ & 0.770 & 0.000 & 0 & 1 \\
\hline $\mathrm{CD}^{+}$ & 0.947 & 0.000 & 0 & 1 \\
\hline $\mathrm{CD}^{+}{ }^{+} \mathrm{PD}-1^{+}$ & 0.650 & 0.024 & 0.054 & 0.975 \\
\hline
\end{tabular}

AUC Area Under ROC Curve 


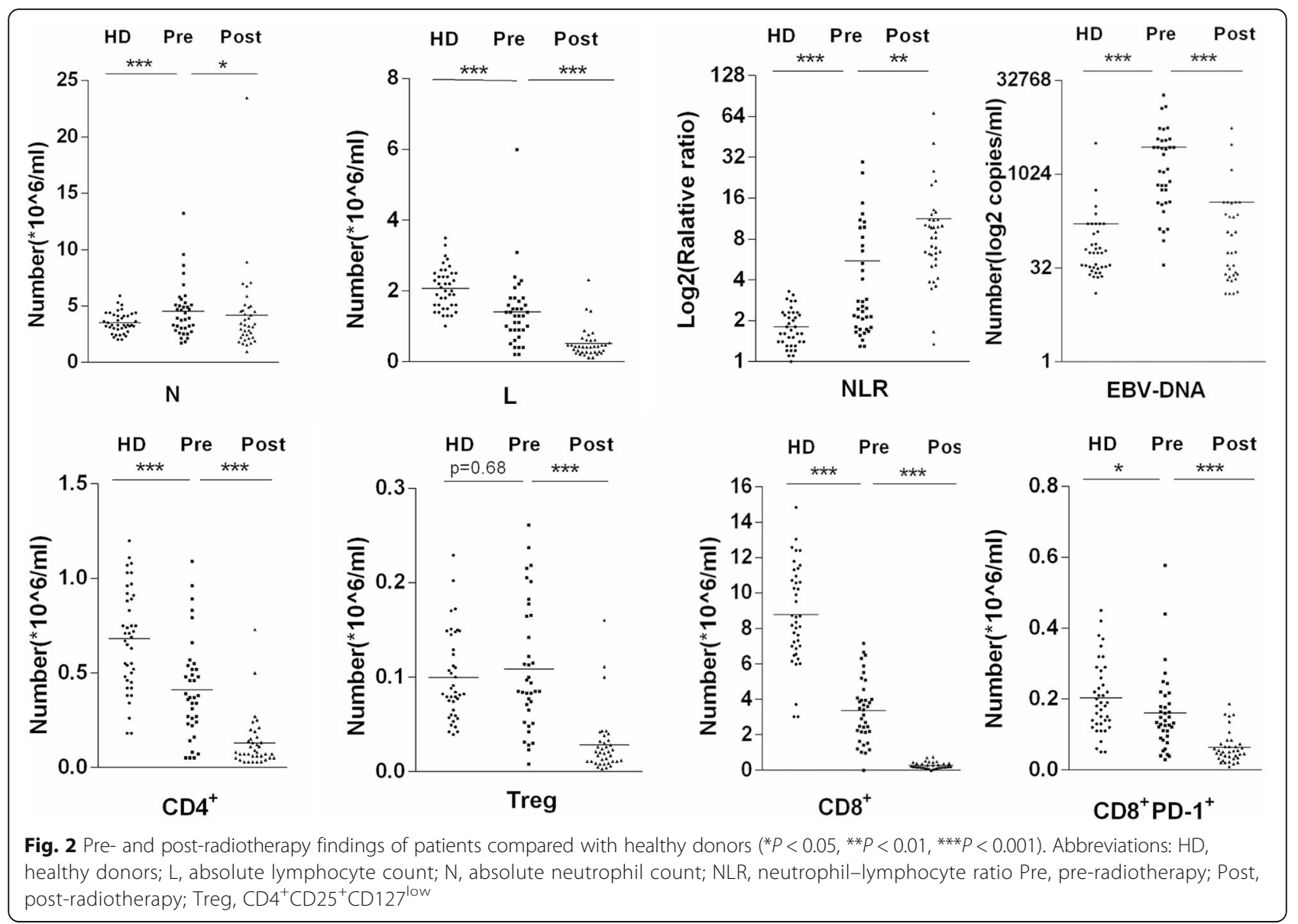

Number of various immune cells and concentration of plasma EBV-DNA in patients with NPC before and after treatment with IMRT and HD

The changes in HD were compared, and the changes in different stages were also investigated.

Further, the indexes were compared and analyzed between the pretreatment and healthy donor groups. The number of immune cells and the concentration of EBV-DNA obviously increased in the pretreatment group $[P<0.01$, odds ratio (OR) $0.02,95 \%$ confidence interval (CI) 0.00-0.20)]. No significant difference was observed in the number of Treg cells between the pretreatment and healthy donor groups, although the $P$ value was higher than 0.05 (OR $0.86,95 \%$ CI $0.35-2.10$ ). The numbers of lymphocytes and $\mathrm{CD}^{+}, \mathrm{CD}^{+}$, and $\mathrm{CD} 8^{+} \mathrm{PD}-1^{+}$cells obviously decreased in the pretreatment group $(P<0.05$, OR 9.50, 20.06, and 3.17 ) (Table 2$)$. Importantly, the study focused on the number of lymphocytes, neutrophil-lymphocyte ratio (NLR), concentration of plasma EBV-DNA, and numbers of $\mathrm{CD}_{4}^{+}, \mathrm{CD}^{+}$, and $\mathrm{CD}^{+} \mathrm{PD}-1^{+}$cells to plot ROC curves. The concentration of plasma EBV-DNA had the highest values of area under the curve, sensitivity, and specificity (Table 3 ).
The results were also compared between the pretreatment and post-treatment groups. The number of lymphocytes, NLR, concentration of plasma EBV-DNA, and numbers of $\mathrm{CD}^{+}, \mathrm{CD}^{+}$, and $\mathrm{CD} 8^{+} \mathrm{PD}-1^{+}$cells remarkably decreased after treatment with IMRT $(P<0.01)$ (Fig. 2$)$. In the present study, the absolute numbers of neutrophils and lymphocytes, neutrophil-lymphocyte ratio, and numbers of $\mathrm{CD}_{4}^{+} \mathrm{T}, \mathrm{CD}^{+} \mathrm{T}, \mathrm{CD}^{+} \mathrm{PD}^{-} 1^{+}$, and Treg cells. In 37 patients with NPC, different clinical stages showed different expression levels. The late stage showed a significantly higher concentration of plasma EBVDNA compared with other stages $(P<0.05)$. At the same time, the late stage showed a notably fewer number of $\mathrm{CD}^{+} \mathrm{T}$ cells $(P<0.05)$ and $\mathrm{CD} 8^{+} \mathrm{PD}-1^{+} \mathrm{T}$ cells compared with other stages $(P<0.01)$ (Fig. 3$)$. The study also analyzed the relationship between TNM stages and various indexes (Fig. 4). The stage of T3+ T4 showed a significantly higher concentration of plasma EBV-DNA $(P<0.01)$. Conversely, other indexes showed lower values $(P<0.05)$. Lymphatic and distant metastases had fewer numbers of $\mathrm{CD}^{+} \mathrm{PD}-1^{+} \mathrm{T}$ cells compared with other stages $(P<0.05)$. 


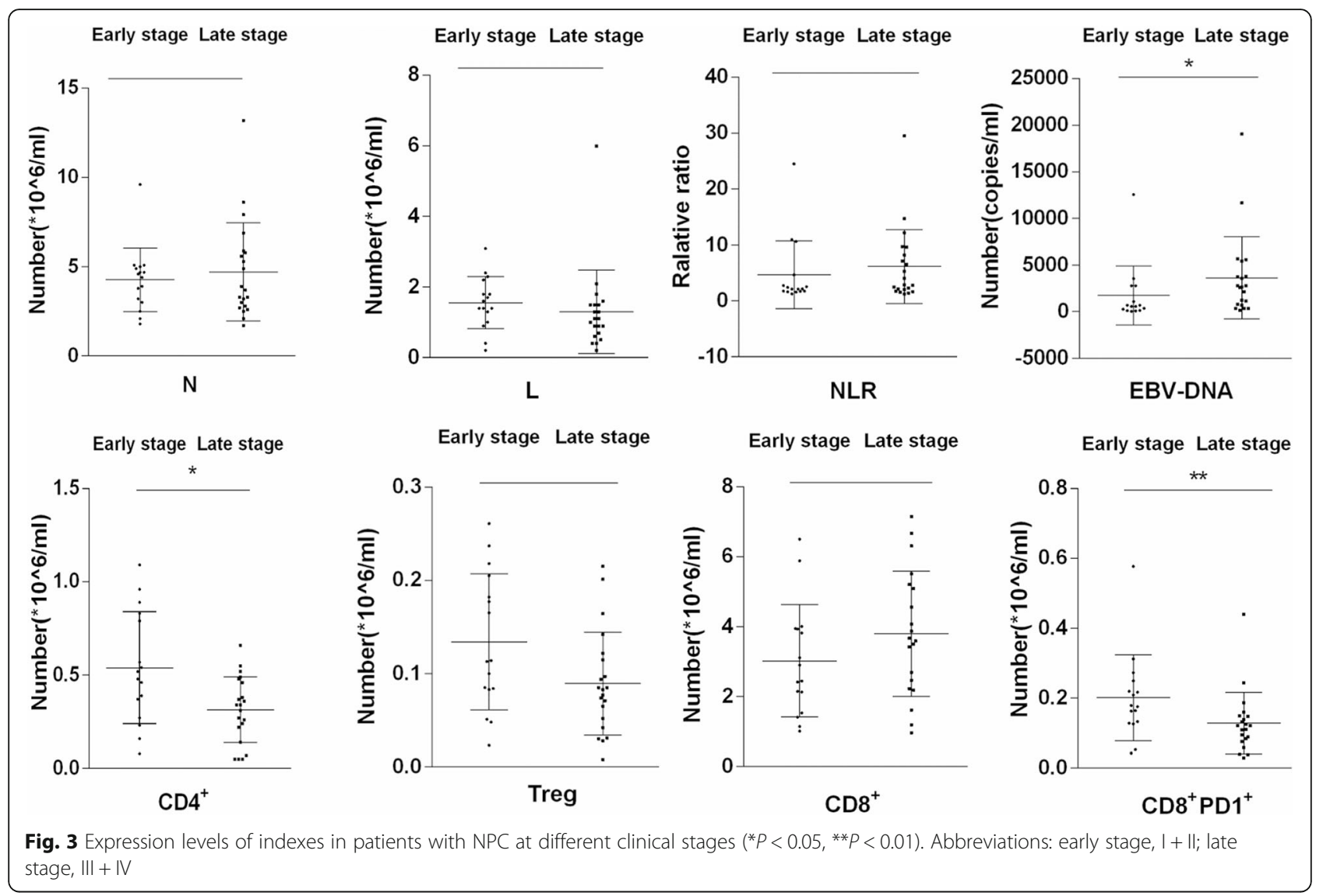

Relationship between the prognosis and immune status for patients with NPC

All patients were followed up. Kaplan-Meier survival analysis showed that the concentration of plasma EBVDNA was positively associated with worse overall survival $(\mathrm{OS})(P=0.021)$. The numbers Treg and $\mathrm{CD}^{+}$ PD- $1^{+}$T cells were negatively associated with worse OS $(P=0.627, P=0.158)$ (Fig. 5).

\section{Discussion}

NPC is a kind of malignant tumor originating from the epithelial tissue. In China, it is mainly distributed in southern provinces, such as Guangdong, Guangxi, Fujian, Zhejiang, and so on. Despite a traditional treatment that combines radiotherapy with chemotherapy, NPC has a high mortality rate because of tumor metastasis [6-8]. Therefore, novel modes of detecting and treating NPC need to be developed and validated [7, 8]. Recently, IMRT has been widely used for treating NPC. Novel molecular markers that can help detect the risk of tumor recurrence are urgently required [9].

Chen et al. [10] found that the number of Treg cells obviously increased in patients with NPC. In the present study, the number of Treg cells increased in the pretreatment group compared with the healthy donor group, though with some insignificant differences. Also, the number of Treg cells significantly decreased after IMRT. Treg cells control autoimmune reactivity of the T-cell subgroup. They are a key factor in tumor immune escape [11]. The number of Treg cells, an immunosuppressive index, increased in patients with NPC, and IMRT treatment could reduce immunosuppression. The difference in the number of Treg cells between the present study and previous studies might be due to the sample size and the number of patients.

T lymphocytes are an important part of cellular immunity in vivo. Especially $\mathrm{CD} 8^{+} \mathrm{T}$ lymphocytes (CTLs) have a key role in the recognition and killing of tumor cells. First, the activation of $\mathrm{T}$ cells requires the recognition of $\mathrm{T}$ cell receptor (TCR) TCR and the presentation of APC. Second, the participation of costimulatory signals is also crucial. These two factors synergistically lead to the activation of $\mathrm{T}$ cells. The costimulatory molecules are divided into two categories: positive and negative, of which CTLA-4 and PD-1 are negative costimulatory molecules. Compared with CTLA-4, PD-1 regulates immune responses more negatively and widely [12]. Besides, $\mathrm{CD} 8^{+} \mathrm{PD}-1^{+}$cells are considered as a representative subpopulation of negative activation of $\mathrm{T}$ cells, and PD-1 inhibits Akt phosphorylation by interfering with CD28-mediated PI3K activation, thereby weakening the activation of $\mathrm{T}$ cells by 


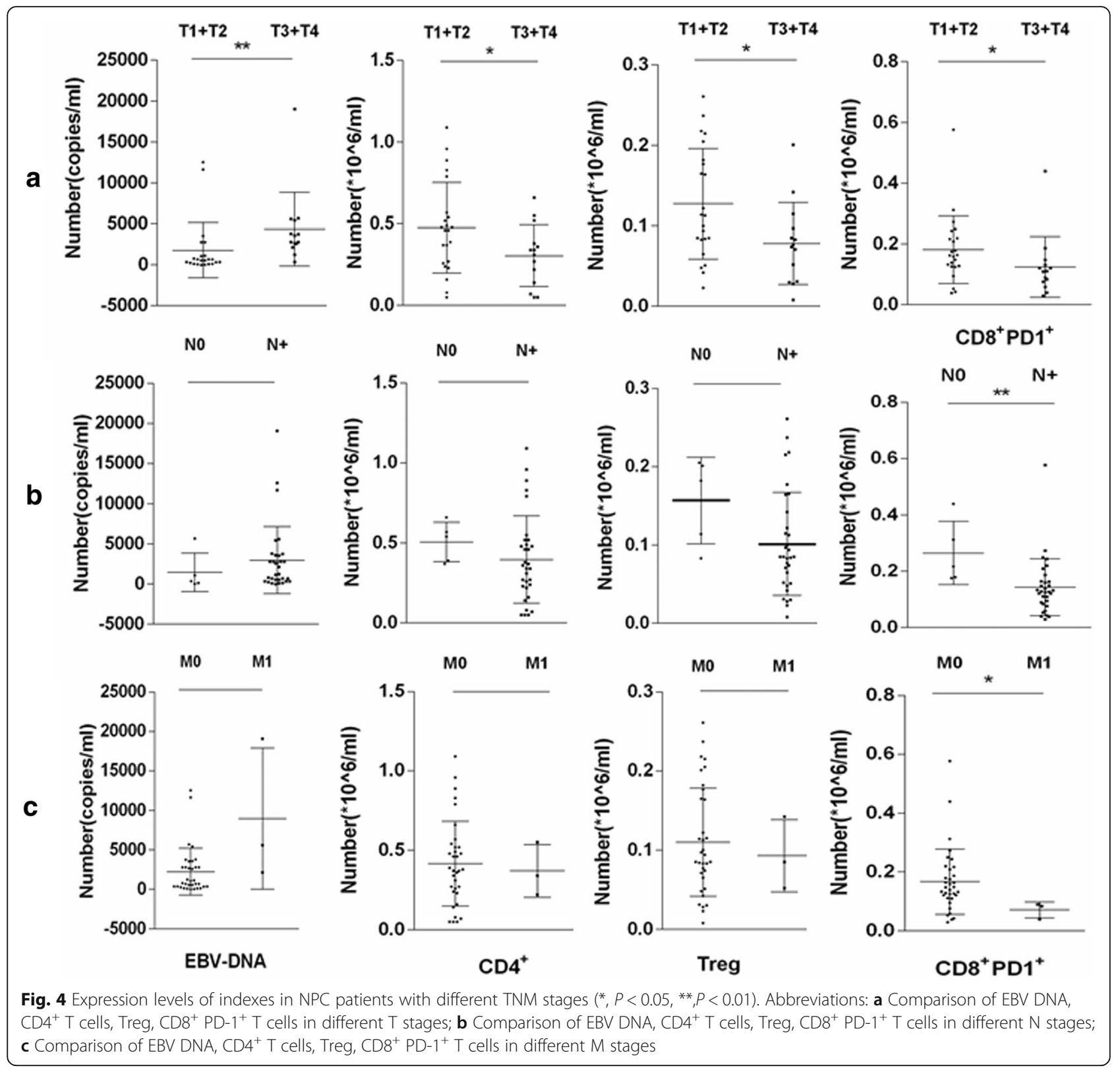

TCR/CD28 signaling [13]. Second, PD-1 reduces the phosphorylation level of PKC, attenuating the effects of PKC and Ras/MAPK. This leads to a decrease in the expression of transcription factors, such as nuclear factor-kappa B and AP-1. PD-1 can inhibit T-cell proliferation, cytokine secretion, and other immune activities [14]. The PD-1 signaling pathway also inhibits the proliferation of $\mathrm{T}$ cells by inhibiting the expression of anti-apoptotic gene BCL-XL [15]. Therefore, the CD $8^{+} \mathrm{PD}-1^{+}$T-cell subset is an important indicator for T-cell exhaustion.

Some studies reported the expression level of PD-1 in tumors, including NPC, hepatic-cellular cancer, breast cancer, renal cell carcinoma, non-small cell lung carcinoma
(NSCLC), high-grade serous carcinoma, and so on [16-20]. Previous studies suggested that PD-1 gene correlated with a poor tumor prognosis, and PD1/ PD-L1 axis had great potential as a treatment target. However, the expression level of PD-1 in NPC is not consistent with that reported in the present study. Larbcharoensub et al. [21] reported that approximately $70 \%$ of patients with EBV-positive NPC expressed PD-L1, but this did not correlate with patient's survival or clinicopathological features. PD-1 in tumors was expressed in only 13 (out of 114) patients. Tang et al. assessed the expression level of PD-1 in a cohort of 96 paraffin-embedded NPC samples and confirmed that PD-1 was co-expressed in infiltrating lymphocytes in patients with NPC [22]. 


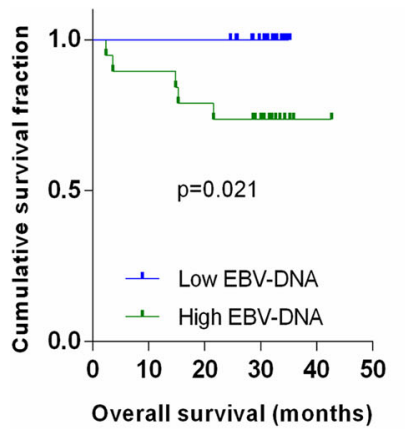

a

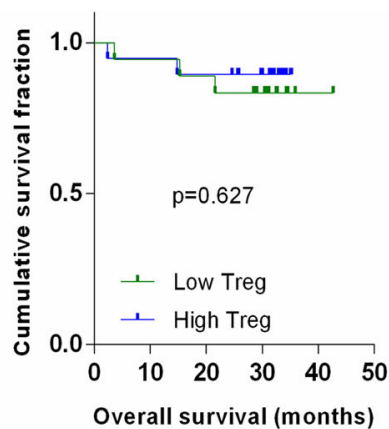

b

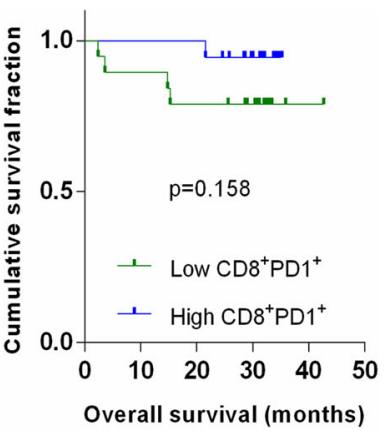

c

Fig. 5 Kaplan-Meier analysis of OS. a The concentration of plasma EBV-DNA was evaluated according to the median (1132.56 copies/mL); more than the median was high, while the opposite was low. $\mathbf{b}$ The number of Treg cells was evaluated according to the median $\left(0.085 \times 10^{6}\right)$; more than the median was high, while the opposite was low. c The number of $\mathrm{CD} 8^{+} \mathrm{PD}-1^{+} \mathrm{T}$ cells was evaluated according to the median $(0.133 \times$ $10^{6}$ ); more than the median was high, while the opposite was low

Zhang et al. [23] further reported that PD-1 association with PD-L1 in patients with NPC correlated with the worst prognosis of disease-free survival. Chan et al. [24] implied EBV-DNA in plasma specimens of participants who did not have any symptoms of NPC. Fang et al. [16] also reported that blocking of PD-1/PD-L1 checkpoints might be a promising therapeutic approach for patients with EBV-positive NPC.

In this study, the concentration of plasma EBV-DNA and the numbers of Treg and $\mathrm{CD} 8^{+} \mathrm{PD}-1^{+}$cells were closely associated with the occurrence and development of NPC. Because of high sensitivity and specificity, plasma EBV-DNA can be used as an important marker for early diagnosis. To explore the changes after IMRT, the numbers of neutrophils, lymphocytes, and $\mathrm{CD}^{+}$, Treg, $\mathrm{CD} 8^{+}$, and $\mathrm{CD}^{+} \mathrm{PD}^{+}$cells and the concentration of plasma EBV-DNA, were compared between the pretreatment and post-treatment groups, revealing no significant differences. IMRT can reduce the expression level of PD-1 and Treg cells, suggesting that IMRT can reverse T-cell exhaustion $[25,26]$. The concentration of plasma EBV-DNA also notably declined after IMRT. It was assumed that T-cell exhaustion led to a massive amplification of plasma EBV-DNA in patients with NPC.

\section{Conclusions}

This study found that IMRT could reverse T-cell exhaustion and reduce the concentration of EBV-DNA. In clinical practice, plasma EBV-DNA is a sensitive biomarker for diagnosis, prognosis, and evaluation of clinical efficacy. This is also in agreement with previous findings [23, 24].

\section{Acknowledgements}

Not applicable.

\section{Funding}

This study was supported in part by the Department of Science and Technology of Zhejiang province (No. 2015C33257) and the Department of Science and Technology of Zhejiang province (No. 2016C33230).

\section{Availability of data and materials}

All data for this study are presented in the manuscript.

Authors' contributions

All co-authors approved the manuscript.

\section{Consent for publication}

Not applicable.

\section{Competing interests}

The authors declare that they have no competing interests.

\section{Publisher's Note}

Springer Nature remains neutral with regard to jurisdictional claims in published maps and institutional affiliations.

\section{Author details}

${ }^{1}$ Precision Medicine Center, Taizhou Central Hospital (Taizhou University Hospital), Taizhou, Zhejiang, People's Republic of China. ${ }^{2}$ Department of Radiotherapy, Taizhou Central Hospital (Taizhou University Hospital), Taizhou, Zhejiang 318000, People's Republic of China. ${ }^{3}$ Department of Pathology, Taizhou Central Hospital (Taizhou University Hospital), Taizhou, Zhejiang, People's Republic of China.

Received: 5 November 2018 Accepted: 4 March 2019

Published online: 14 March 2019

\section{References}

1. Chen W, Zheng R, Baade PD, Zhang S, Zeng H, Bray F, et al. Cancer statistics in China, 2015. CA Cancer J Clin. 2016;66:115-32.

2. Zhang $L$, Chen $Q Y, L i u ~ H$, Tang LQ, Mai HQ. Emerging treatment options for nasopharyngeal carcinoma. Drug Des Devel Ther. 2013;7:37-52.

3. Postow MA, Callahan MK, Barker CA, Yamada Y, Yuan J, Kitano S, et al. Immunologic correlates of the abscopal effect in a patient with melanoma. N Engl J Med. 2012;366:925-31.

4. Golden EB, Chhabra A, Chachoua A, Adams S, Donach M, FentonKerimian M, et al. Local radiotherapy and granulocyte-macrophage colony-stimulating factor to generate abscopal responses in patients with metastatic solid tumours: a proof-of-principle trial. Lancet Oncol. 2015;16:795-803.

5. Hu W, Wang W, Yang P, Zhou C, Yang W, Wu B, et al. Phase I study of icotinib, an EGFR tyrosine kinase inhibitor combined with IMRT in nasopharyngeal carcinoma. Int J Clin Exp Med. 2015;8:15675-83.

6. Okazaki T, Honjo T. PD-1 and PD-1 ligands: from discovery to clinical application. Int Immunol. 2007:19:813-24.

7. Blanchard P, Lee A, Marguet S, Leclercq J, Ng WT, Ma J, et al. Chemotherapy and radiotherapy in nasopharyngeal carcinoma: an update of the MAC-NPC meta-analysis. Lancet Oncol. 2015;16:645-55. 
8. Lee AW, Ng WT, Chan YH, Sze H, Chan C, Lam TH. The battle against nasopharyngeal cancer. Radiother Oncol. 2012;104:272-8.

9. Al-Sarraf M, LeBlanc M, Giri PG, Fu KK, Cooper J, Vuong T, et al. Chemoradiotherapy versus radiotherapy in patients with advanced nasopharyngeal cancer: phase III randomized intergroup study 0099. J Clin Oncol. 1998;16:1310-7.

10. Chen M, Jin F, Ma L. The detection and significance of $T$ cells in nasopharyngeal carcinoma patients. J Cancer Res Ther. 2018;14:331-5.

11. Chen X, Du Y, Lin X, Qian Y, Zhou T, Huang Z. CD4+CD25+ regulatory T cells in tumor immunity. Int Immunopharmacol. 2016;34:244-9.

12. Luan $\mathrm{Y}$, Chai D, Peng J, Ma S, Wang M, Ma H, et al. A fully human monoclonal antibody targeting PD-L1 with potentanti-tumor activity. Int Immunopharmacol. 2016;31:248-56.

13. Fife BT, Pauken KE, Eagar TN, et al. Interactions between PD-1 and PD-L1 promote tolerance by blocking the TCR-induced stop signa1. Nat Immunol. 2009;10:1185-1192

14. Parry RV, Chemnitz JM, Frauwirth KA, et al. CTLA-4 and PD-1 receptors inhibit T-cell activation by distinct mechanisms [J]. Mol Cell Biol. 2005;25(21):9543-53.

15. Tewalt EF, Cohen JN, Rouhani SJ, et al. Lymphatic endothelial cells induce tolerance via PD-L1 and lack of co-stimulation leading to high-level PD-1 expression on CD8 T cells [J]. Blood. 2012:120(24):4772-82.

16. Fang W, Zhang J, Hong S, Zhan J, Chen N, Qin T, et al. EBV-driven LMP1 and IFN-gamma up-regulate PD-L1 in nasopharyngeal carcinoma: implications for oncotargeted therapy. Oncotarget. 2014;5:12189-202.

17. Luan Y, Chai D, Peng J, Ma S, Wang M, Ma H, et al. A fully human monoclonal antibody targeting PD-L1 with potent anti-tumor activity. Int Immunopharmacol. 2016;31:248-56.

18. Weinstock M, McDermott D. Targeting PD-1/PD-L1 in the treatment of metastatic renal cell carcinoma. Ther Adv Urol. 2015;7:365-77.

19. Kolacinska A, Cebula-Obrzut B, Pakula L, Chalubinska-Fendler J, MorawiecSztandera A, Pawlowska Z, et al. Immune checkpoints: cytotoxic Tlymphocyte antigen 4 and programmed cell death protein 1 in breast cancer surgery. Oncol Lett. 2015;10:1079-86.

20. Sasaki H, Tatemaysu T, Okuda K, Moriyama S, Yano M, Fujii Y. PD-1 gene promoter polymorphisms correlate with a poor prognosis in non-small cell lung cancer. Mol Clin Oncol. 2014:2:1035-42

21. Larbcharoensub N, Mahaprom K, Jiarpinitnun C, et al. Characterization of PD-L1 and PD-1 expression and CD8 ${ }^{+}$tumor-infiltrating lymphocyte in Epstein-Barr virus-associated nasopharyngeal carcinoma. Am J Clin Oncol. 2018;12:1204-10.

22. Tang Y, He Y, Shi L, et al. Co-expression of AFAP1-AS1 and PD-1 predicts poor prognosis in nasopharyngeal carcinoma. Oncotarget. 2017;24:39001-11.

23. Zhang J, Fang W, Qin T, Yang Y, Hong S, Liang W, et al. Co-expression of PD-1 and PD-L1 predicts poor outcome in nasopharyngeal carcinoma. Med Oncol. 2015;32:86

24. Chan KA, Woo JK, King A, Zee BC, Lam WJ, Chan SL, Chu SW, Mak C, Tse IO, Leung SY, Chan G. Analysis of plasma Epstein-Barr virus DNA to screen for nasopharyngeal cancer. N Engl J Med. 2017;6:513-22.

25. Pauken KE, Wherry EJ. SnapShot: T cell exhaustion. Cell. 2015;163:10381038 e1031.

26. Postow MA, Callahan MK, Wolchok JD. Immune checkpoint blockade in cancer therapy. J Clin Oncol. 2015;33:1974-82.

Ready to submit your research? Choose BMC and benefit from:

- fast, convenient online submission

- thorough peer review by experienced researchers in your field

- rapid publication on acceptance

- support for research data, including large and complex data types

- gold Open Access which fosters wider collaboration and increased citations

- maximum visibility for your research: over $100 \mathrm{M}$ website views per year

At BMC, research is always in progress.

Learn more biomedcentral.com/submissions 